\title{
Rapid Solidification of an Al-5Ni Alloy Processed by Spray Forming
}

\author{
Conrado Ramos Moreira Afonso a, José Eduardo Spinelli*, Claudemiro Bolfarini ${ }^{a}$, \\ Walter José Botta ${ }^{\text {a }}$ Claudio Shyinti Kiminami ${ }^{\mathrm{a}}$ Amauri Garcia \\ ${ }^{a}$ Department of Materials Engineering, Federal University of São Carlos - UFSCar, \\ Rod. Washington Luis, Km 235, CEP 13565-905, São Carlos, SP, Brazil \\ ${ }^{\mathrm{b}}$ Department of Materials Engineering, University of Campinas - UNICAMP, \\ CP 6122, CEP 13083-860, Campinas, SP, Brazil
}

Received: November 23, 2011; Revised: February 28, 2012

\begin{abstract}
Recently, intermetallic compounds have attracted much attention due to their potential technological applications as high-temperature materials. In particular the intermetallic compounds, associated with the Al-Ni binary system stand out as promising candidates for high-temperature materials for the use in harsh environments. It is expected that a bulk Al-Ni alloy may exceed the strength of many commercial materials. The great challenge in developing these alloys is to manipulate the solidification thermal parameters in order to obtain the desired microstructural features. One of the indicated routes to obtain very refined intermetallic phases dispersed in the microstructure is the spray forming process. The dendritic and eutectic growth dependences on cooling rate are already known for directionally solidified (DS) hypoeutectic Al-Ni alloys. In the case of rapidly solidified (RS) samples, extrapolations of such experimental laws are needed, which can be very helpful to estimate realistic values of high cooling rates imposed during the spray forming process. The present study aims to compare directionally solidified and spray-formed Al-5 wt. (\%)Ni alloy samples with a view to providing a basis for understanding how to control solidification parameters and the as-cast microstructure. The Al-5.0 wt. (\%)Ni alloy was shown to have a cellular morphology for the overspray powder size range examined (up to $500 \mu \mathrm{m}$ ). The mean cell spacing decreased from 5.0 to $1.1 \mu \mathrm{m}$ with the decrease in the powder average diameter. It was found that the experimental cooling rates imposed during the atomization step of the overspray powder solidification varied from $10^{3}$ to $2.10^{4} \mathrm{~K} / \mathrm{s}$. The DSC trace depicted a crystallization peak of an amorphous structure fraction in the smallest Al-5.0 wt. (\%)Ni alloy powder size range $(<32 \mu \mathrm{m})$ estimating a $15 \mu \mathrm{m}$ critical diameter of amorphous powder in the binary $\mathrm{Al}_{97.5} \mathrm{Ni}_{2.5}($ at $\%)$ alloy.
\end{abstract}

Keywords: Al-Ni alloys, microstructure, microhardness, spray forming, amorphous phase

\section{Introduction}

Very fine Al-Ni powders obtained by gas atomization processes have been used to produce Raney nickel catalysts in order to promote the appropriate reactions in hydrogen fuel cells. Tourret et al. ${ }^{1}$ stated that the catalytic activity depends on the amount of phases in the atomized powders. The desired microstructural arrangement is mainly affected by alloy composition and powder size. One of the routes indicated to obtain very refined intermetallics in metallic alloys is the spray forming process. Spray forming, also called spray casting or spray deposition, involves the inert gas atomization of a liquid metal stream into variously sized droplets which are then propelled away from the region of atomization by the fast flowing, atomizing gas ${ }^{2-4}$. The droplet trajectories are interrupted by a substrate which collects and solidifies the droplets into a coherent, near fully dense deposit. By a continuous movement of the substrate with respect to the atomizer as deposition proceeds, large deposits can be produced in a variety of geometries including tubes and strips ${ }^{2-4}$. As-spray formed deposits always contain some

*e-mail: spinelli@ufscar.br inherent porosity (1-10\%) and are usually consolidated to full density by extrusion, hot/cold rolling or hot isostatic pressing (HIP). The powder which was not incorporated in the deposit and was collected in the bottom of the atomization chamber is called overspray powder and is usually about $20 \mathrm{wt}$. (\%) of the starting charge ${ }^{2-4}$.

Several thermal spray techniques ${ }^{5}$ have been used in order to apply Al-Ni intermetallics in the form of thick coatings. However, difficulties to obtain well-dispersed $\mathrm{Al}_{3} \mathrm{Ni}, \mathrm{Al}_{3} \mathrm{Ni}_{2}$ and AlNi particles have been reported ${ }^{5}$. Such intermetallics are emerging as important materials for nanotechnology applications with recent examples of use of bimetallic Al-Ni reactive nanostructures as nano-heaters ${ }^{6}$. In addition, the association of a refined structure and a considerable fraction of $\mathrm{Al}-\mathrm{Ni}$ intermetallics may result in high hardness and, as a consequence, high mechanical strength. It is expected that a bulk Al-Ni alloy may exceed the strength of many commercial materials ${ }^{7}$. Although the ultimate tensile stress of commercially available Al-based 'high-strength' alloys (e.g. Al-Cu-Mg, $\mathrm{Al}-\mathrm{Zn}-\mathrm{Mg}-\mathrm{Cu}$ and 
Al-Si-Mg) approaches $700 \mathrm{MPa}$, their 'high-strength state' remains only at low temperatures $\left(<200{ }^{\circ} \mathrm{C}\right)^{7}$. In contrast, the hard $\mathrm{Al}_{3} \mathrm{Ni}$ particles are not only able to induce a high mechanical strength in $\mathrm{Al}-\mathrm{Ni}$ alloys but are also considered to be thermally stable up to $\sim 500{ }^{\circ} \mathrm{C}^{8}$. It is well-established that automotive parts such as connecting rod, cylinder sleeve, piston and valve retainer as well as compressor parts such as the rotary compressor vane and shoe disc may be manufactured with Al-Ni alloys ${ }^{9}$.

A Vickers microhardness value of about $150 \mathrm{HV}$ was obtained by Vojtech et al. ${ }^{7}$ during the evaluation performed in a rapidly solidified $\mathrm{Al}_{95} \mathrm{Ni}_{5}$ (at\%) by centrifugal atomization. The DSC records obtained for a granulometric fraction smaller than $250 \mu \mathrm{m}$ showed no evidences of exothermal effects at low temperatures of about $150-300{ }^{\circ} \mathrm{C}$ which would correspond to the crystallization of an amorphous phase. Cheung et al. ${ }^{10}$ reported mean Vickers microhardness values of $103 \mathrm{HV}$ in the dendritic region and $183 \mathrm{HV}$ in the lamellar region of an Al-5Ni alloy sample which was subjected to a laser surface remelting process (LSR). This laser treatment is characterized by very rapid heat extraction during solidification resulting in very high cooling rates of the order of $10^{5}-10^{8} \mathrm{~K} / \mathrm{s}$. The effects of melt spinning technique on hardness of Al-Ni alloys have been investigated by Gogebakan et al. ${ }^{11}$. It was found that rapidly solidified Al-6.5 wt. (\%)Ni alloy ribbons had microhardness values of about two times higher than that of the corresponding chillcasting alloy. In this study SEM micrographs of the meltspun Al-6.5 wt. (\%)Ni alloy showed cells surrounded by a eutectic mixture for lower solidification rates (4 to $7 \mathrm{~m} / \mathrm{s}$ ) while fine dendritic arrays prevailed for higher solidification rates $(8$ and $10 \mathrm{~m} / \mathrm{s})$. The presence of dendritic branches is due to the increase of the solid solubility limit of nickel in the $\alpha$-Al, which may be effective during rapid solidification.

Lapin et al. ${ }^{12}$ performed directional solidification experiments with Ti-based alloys in a modified Bridgman-type apparatus. A linear relationship between the compression yield stress and microhardness has been determined. Such results have demonstrated that mechanical properties of directionally solidified castings can be predicted from appropriate Vickers microhardness measurements. Moreover, Fan et al. ${ }^{13}$ stated that microhardness analysis seems to be a relatively simple way to accomplish the complex task of predicting mechanical properties of materials. In the case of Ti-Al alloys the values of Vickers microhardness (HV) are already used for quality control in the production of turbochargers, automotive valves and compressor blades.

The absence or presence of amorphous phase in RS Al-Ni based alloys can be explained in terms of their chemical composition ${ }^{7}$. It is generally agreed that the formation of a glassy phase would require higher nickel content. Nevertheless, experimental reports regarding the amorphous phase dependence on nickel composition of RS alloys are scarce in the literature.

Kong et al. ${ }^{14}$ reported that microstructures formed in gas-atomized Al-Sn-Cu powders depend on the diameter of the powder particle. In large particles $(>8 \mu \mathrm{m})$ a cellular/dendritic morphology comprising $\alpha$-Al dendrites/cells and an interdendritic Sn-rich phase was observed. However, for particles having sizes $<8 \mu \mathrm{m}$, the Sn-rich phase appears finely dispersed within the $\alpha$-Al matrix. A simple experimental linear law has been proposed by Tourret et al. ${ }^{1}$ correlating the secondary dendrite arm spacing $\left(\lambda_{2}\right.$ in $\left.\mu \mathrm{m}\right)$ as a function of the droplet diameter (D in $\mu \mathrm{m}$ ) for $\mathrm{Al}_{75} \mathrm{Ni}_{25}$ : $\lambda_{2}=1.0+0.25$ (D).

The dendritic and eutectic growth dependences on the cooling rate are already known for directionally solidified hypoeutectic Al-Ni alloys ${ }^{15}$. Canté et al. ${ }^{15}$ stated that the variation in the experimental primary dendritic arm spacing with the cooling rate for Al-1.0 to $5.0 \mathrm{wt}$. (\%) Ni alloys can be fitted by -0.5 power laws. In the case of rapidly solidified samples, extrapolations of such experimental laws are needed, which can be very helpful to estimate realistic values of cooling rate during the spray forming process.

An Al-5.0 wt. (\%)Ni alloy processed through a spray forming process has been examined in the present study. The aim of this work is the investigation of: the microstructural evolution as a function of powder size and the dependence of cell spacing with the cooling rate imposed during the atomization step. Experimental results include microstructural characterization of Al-Ni powders using scanning electron microscope (SEM) coupled to EDS, optical microscopy, X-ray diffraction (XRD) and differential scanning calorimetry (DSC). Powder compaction was carried out to permit experimental Vickers microhardness measurements.

\section{Experimental Procedure}

The spray forming process also named spray casting or spray deposition is based on the inert gas atomization of a liquid metal stream into variously sized droplets which are then propelled away from the region of atomization by the fast flowing atomizing gas (Figure 1). The Al-5 wt. (\%)Ni alloy was processed through an atomizer Osprey ${ }^{\mathrm{TM}}$. Commercially pure grade (c.p.): Al (99.887 wt. (\%)), Ni (99.896 wt. (\%)) were used to prepare the Al-Ni samples. The mean impurities

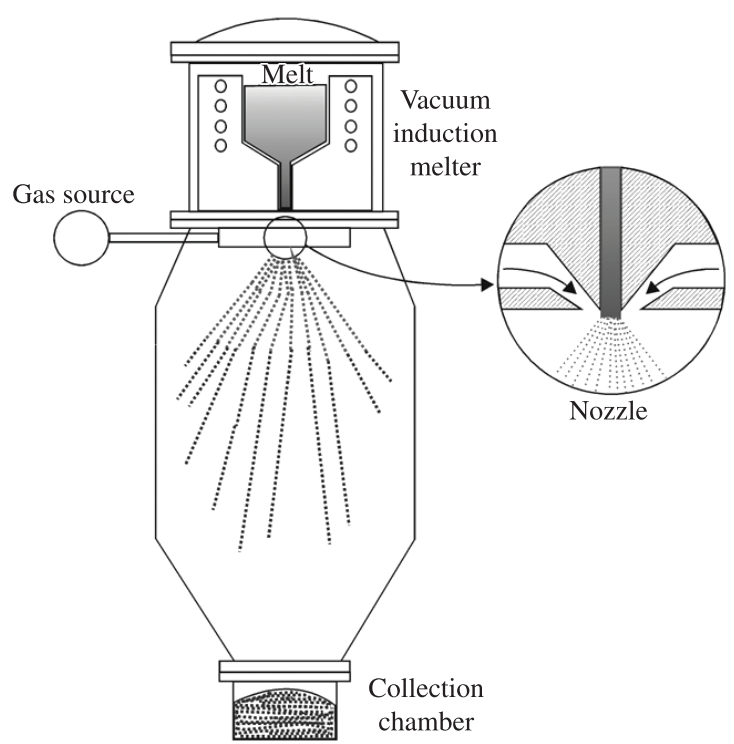

Figure 1. Schematic representation of the spray forming process. 
detected were: $\mathrm{Fe}(0.059 \%), \mathrm{Si}(0.042 \%), \mathrm{Sn}(0.0073 \%), \mathrm{Ni}$ $(0.0057 \%)$ and $\mathrm{Pb}(0.0027 \%)$, besides other elements found with concentrations less than $100 \mathrm{ppm}$. A charge, having the nominal alloy composition, weighting about $3.0 \mathrm{~kg}$ was prepared through an induction furnace. The melt was poured via a nozzle of $6 \mathrm{~mm}$ diameter fixed at the bottom of a tundish when the melt temperature was about 5\% above the liquidus temperature. Simultaneously, $\mathrm{N}_{2}$ was injected into the melt stream. The nitrogen flow rate was maintained constant while two pressure values have been adopted: 0.4 and $0.8 \mathrm{MPa}$ (named S1 and S2, respectively). The overspray Al-Ni powder was collected in the bottom of the atomization chamber. Then, the powder was sieved in granulometric size ranges and classified in four different size ranges: between 250 and $180 \mu \mathrm{m} ; 180$ and $106 \mu \mathrm{m} ; 106$ and $88 \mu \mathrm{m}$ and smaller than $88 \mu \mathrm{m}$.

Microstructural characterization of the obtained powders on both S1 and S2 overspray has been performed using an optical microscope associated with an image analysis system Olympus GX51 (Olympus Co., Japan) and a Field Emission Gun (FEG) - Scanning Electron Microscope (SEM) Philips (XL30 FEG) coupled to an Energy Dispersive Spectroscope - EDS (Oxford Link ISIS 300). The powder was re-classified in order to measure the cell spacing $\left(\lambda_{1}\right)$ of each selected size range including the smaller powder sizes. The four size ranges were $>106 \mu \mathrm{m}, 106$ to $45 \mu \mathrm{m}, 45$ to $32 \mu \mathrm{m}$ and $<32 \mu \mathrm{m}$. The triangle method was employed to measure $\lambda_{1}{ }_{1}^{15,16}$. At least 20 measurements were performed for each selected powder size range.

Cold pressing was used to transform the obtained powder (with size smaller than $180 \mu \mathrm{m}$ ) into cylindrical preforms with diameter of $14.6 \mathrm{~mm}$, height of $4.6 \mathrm{~mm}$ and weight of about $2.0 \mathrm{~g}$. The cold pressing of both powders S1 and S2 were made without canning, degassing, and atmosphere control, and were compacted in air at room temperature. The uniaxial stress applied to consolidate the samples was $600 \mathrm{MPa}$.

Microhardness tests were performed by using a test load of $200 \mathrm{~g}$ and a dwell time of 10 seconds. A Stiefelmayer KL2 model hardness measuring test device (Germany) was used. The adopted Vickers microhardness was the average of at least 15 measurements on each pressed sample. The $\mathrm{X}$-ray diffraction (XRD) patterns were obtained in a Siemens D5000 with a 2-theta range from $20^{\circ}$ to $90^{\circ}, \mathrm{Cu}-\mathrm{K} \alpha$ radiation and a wavelength, $\lambda$, of $0.15406 \mathrm{~nm}$. Differential scanning calorimetry (DSC, Netzch 200F3, temperature range $25-500{ }^{\circ} \mathrm{C}$, heating rate of $40 \mathrm{~K} / \mathrm{min}$ ) was used to monitor solid state transformations overspray powder.

\section{Results and Discussion}

The Thermo-Calc software was used to calculate the partial equilibrium phase diagram for the Al-Ni metallic system, as can be seen in Figure 2.

Figure 3 shows that two different distributions for Al-5 wt. (\%)Ni alloy powders have been obtained, with a higher fraction of fine particles $(<106 \mu \mathrm{m})$ found for S2 due to the higher applied pressure and higher gas/metal ratio (G/M). Thus, finer Al-5.0 wt. (\%)Ni alloy powders can be produced by increasing the gas-metal ratio. This is probably
Thermo-calc (20007.05.28:16.48): Al NI

Database: PBIN

$\mathrm{P}=100000, \mathrm{~N}=1$, fixed phases: $\mathrm{AL} 3 \mathrm{NI} 5=0$;

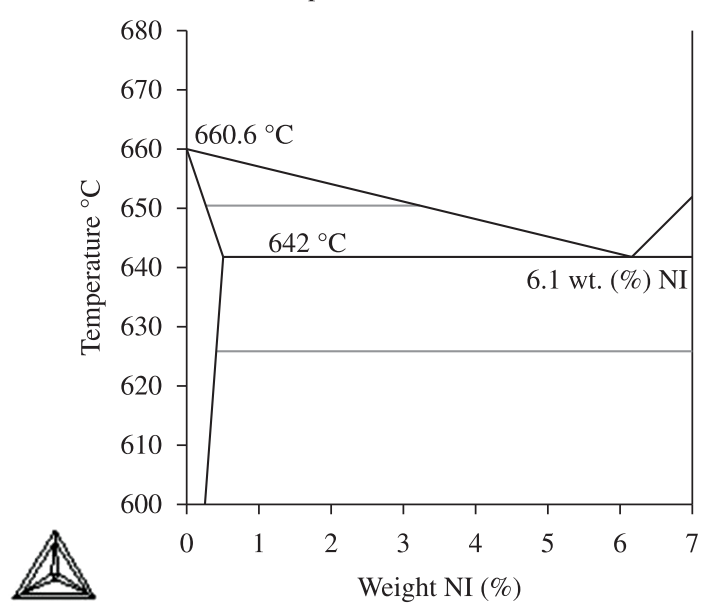

Figure 2. Partial binary phase diagram for Al-Ni.

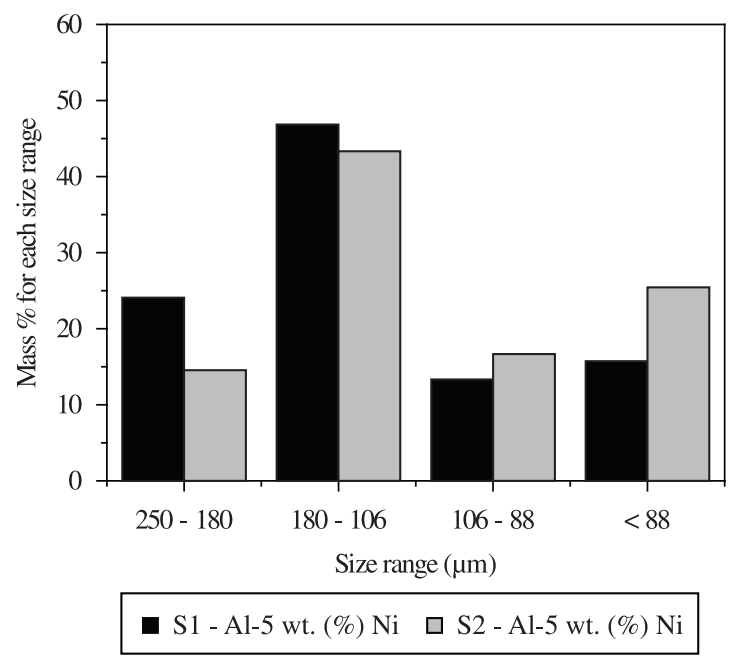

Figure 3. Mass as a function of each selected granulometric size range for overspray powders of the Al-5.0 wt. (\%)Ni alloy.

due to the higher cooling rates obtained as a consequence of the higher $\mathrm{G} / \mathrm{M}$ ratio.

Figure 4 shows the mean experimental $\lambda_{1}$ values of primary dendritic arm spacing as a function of the cooling rate (black squares) as determined by Canté et al. ${ }^{15}$ during unidirectional solidification of an $\mathrm{Al}-5 \mathrm{Ni}$ alloy. It can be seen that the proposed power function $\lambda_{1}=135 \mathrm{~T}^{-0.5}$ fits adequately the experimental scatter. The mentioned authors ${ }^{15}$ have performed unsteady-state directional solidification experiments with a number of hypoeutectic Al-Ni alloys followed by characterization of the transversal and longitudinal as-cast structures and the determination of experimental dendritic growth evolution as a function of growth rate and tip cooling rate.

The mean cell spacing values (black circles) were measured for 4 different powder size ranges $(>106 \mu \mathrm{m}, 106$ to $45 \mu \mathrm{m}, 45$ to $32 \mu \mathrm{m}$ and $<32 \mu \mathrm{m}$ ). The average $\lambda_{1}$ values and their standard deviations of each powder range can be 


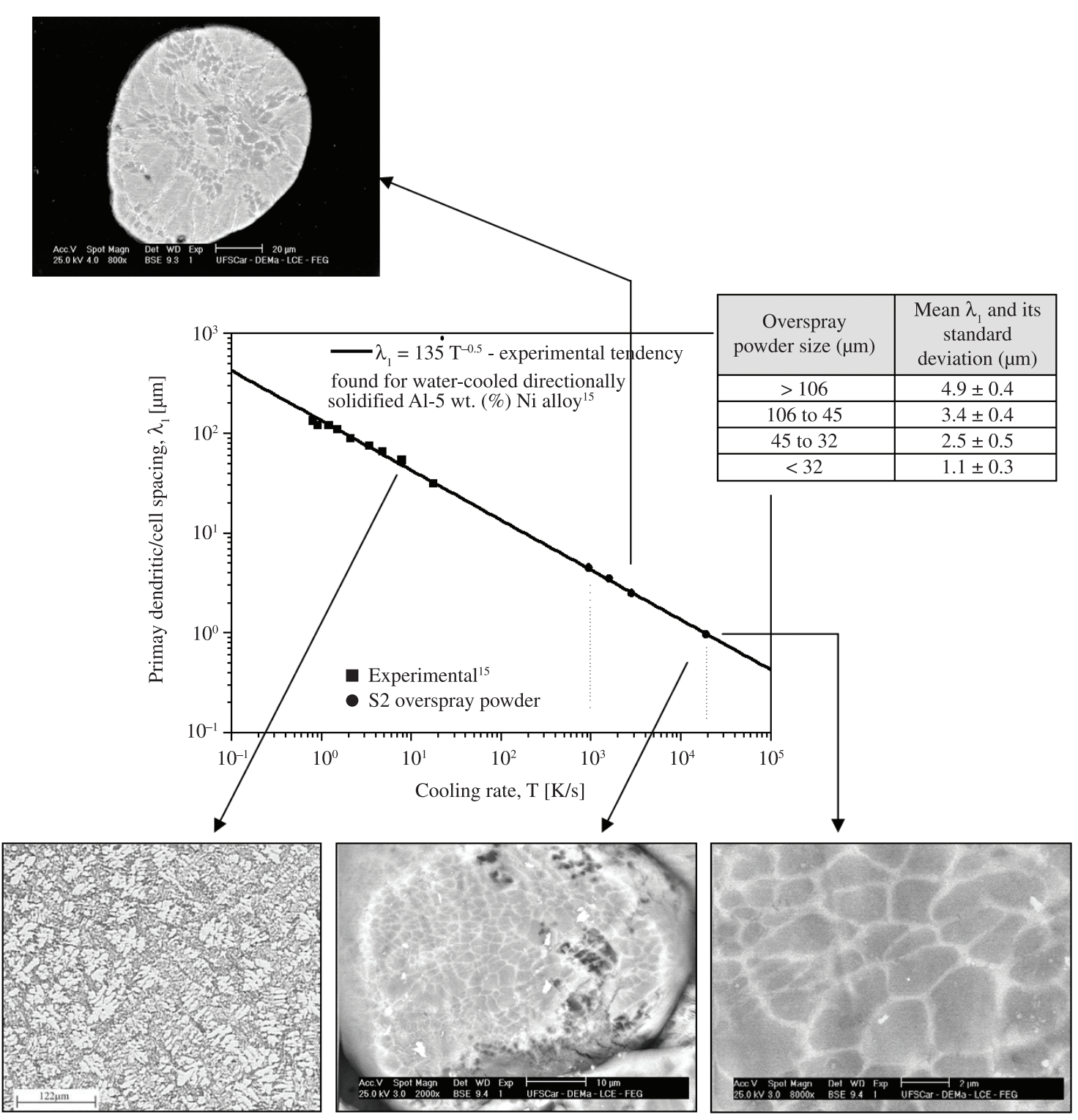

Figure 4. Primary dendritic spacing and cell spacing as a function of cooling rate for Al-5.0 wt. (\%)Ni alloy.

seen in Figure 4. Such values were inserted in order to permit the experimental curve to be continued, and a variation from 5.0 to $1.1 \mu \mathrm{m}$ was observed. As the growth nature of cells is similar to that of primary dendritic branches, the extrapolation of the mentioned experimental dependence for DS samples have permitted the powder cooling rates to be determined (from $10^{3}$ to $2.10^{4} \mathrm{~K} / \mathrm{s}$ ).

Figure 4 shows also typical microstructures obtained from the powders as well as from the DS samples. The microstructure consists of an Al-rich (phase $\alpha$ ) cellular matrix with a eutectic mixture in the intercellular region formed by $\alpha$ and the intermetallic compound $\mathrm{Al}_{3} \mathrm{Ni}$. Average and standard deviations of $\lambda_{1}$ values of about $2.5 \pm 0.5 \mu \mathrm{m}$ and $1.1 \pm 0.3 \mu \mathrm{m}$ were determined at 45 to $32 \mu \mathrm{m}$ and $<32 \mu \mathrm{m}$ ranges, respectively. The mean $\lambda_{1}$ values found for $\mathrm{S} 1$ powders are quite close to those determined for $\mathrm{S} 2$, except for the coarser powders $(>106 \mu \mathrm{m})$, which exhibited a mean value which is $25 \%$ higher than that obtained for $\mathrm{S} 2$ in the same range. According to Kurz and Fisher ${ }^{17}$ the solidification interface morphologies can vary from planar at very low growth rates to cells and to dendrites which become finer and finer until they give rise to cellular-type structures when close to the limit of absolute stability. The cell growth observed in this study is a typical rapid solidification microstructure. The proximity with the absolute stability occurs when the solute diffusion distance approaches the solute capillarity length.

Under equilibrium conditions, the solid solubility of $\mathrm{Ni}$ in $\mathrm{Al}$ is very limited, with a value of 0.023 at $\% \mathrm{Ni}$ $(\sim 0.05$ wt. $(\%))$ being reported ${ }^{11}$. The extension of solid solubility of $\alpha$-Al matrix in Al-5Ni overspray powders was determined by EDS microanalysis and is characterized by a much larger Ni content of about 1.5 at $\% \mathrm{Ni}(\sim 3.0 \mathrm{wt} .(\%))$, due to the rapid quenching promoted during atomization. 
Cooling rate is a key factor affecting the powder microstructure. In order to calculate it during rapid solidification in the atomization step of overspray powders an easy-to-maneuver model was developed by Shiwen et al. ${ }^{18}$. These authors have already reported excellent agreement between simulated and experimental results obtained for gas atomized $\mathrm{Al}-\mathrm{Ni}-\mathrm{Ce}-\mathrm{Fe}-\mathrm{Cu}$ alloys. The proposed equation is simplified as follows:

$$
\dot{T}_{d}=\frac{12}{\rho \times c_{p}}\left(T_{d}-T_{g}\right) \frac{K_{g}}{d^{2}}
$$

where $T_{d}$ is the powder cooling rate, $\rho$ is the density of the molten droplet, $c_{p}$ is the specific heat, $T_{d}$ is the droplet temperature (assumed as the melt pouring temperature), $\mathrm{T}_{\mathrm{g}}$ is the atomizing gas temperature, $\mathrm{k}_{\mathrm{g}}$ is the gas thermal conductivity and $d$ is the size of the droplet. The thermophysical properties necessary for the theoretical calculations are summarized in Table 1.

The calculated value for a powder with diameter of $40 \mu \mathrm{m}$ is $2.8 \times 10^{4} \mathrm{~K} / \mathrm{s}$, which is roughly consistent with the experimental result, i.e., $2.10^{4} \mathrm{~K} / \mathrm{s}$. Moreover, the deviation found in such comparison may be related to the typical

Table 1. Summary of the thermophysical properties necessary to perform the calculations with the Al-5.0 wt. (\%)Ni alloy ${ }^{14,15}$.

\begin{tabular}{cc}
\hline Property (unit) $[$ symbol] & Value \\
\hline Melt density $\left(\mathrm{kg} \cdot \mathrm{m}^{-3}\right)[\rho]$ & 2.644 \\
Specific heat $\left(\mathrm{J} \cdot \mathrm{kg}^{-1} \cdot \mathrm{K}^{-1}\right)\left[\mathrm{c}_{\mathrm{p}}\right]$ & 1.147 \\
Melt droplet temperature $(\mathrm{K})\left[\mathrm{T}_{\mathrm{d}}\right]$ & 953 \\
$\mathrm{~N}_{2}$ temperature $(\mathrm{K})\left[\mathrm{T}_{\mathrm{g}}\right]$ & 400 \\
Powder size $(\mathrm{m})[\mathrm{d}]$ & $4 \times 10 \mathrm{E}^{-5}$ \\
$\mathrm{~N}_{2}$ thermal conductivity at $400 \mathrm{~K}\left(\mathrm{~W} \cdot \mathrm{m}^{-1} \cdot \mathrm{K}^{-1}\right)\left[\mathrm{k}_{\mathrm{g}}\right]$ & 0.32 \\
\hline
\end{tabular}

thermal instabilities of the solidification front during rapid solidification that can provoke variations in $\lambda_{1}$ values. Thus, if considered the minimum $\lambda_{1}$ value of the experimental range, a better agreement can be expected following the same approach.

Figure 5 shows microstructures of samples extracted from the center region of the deposit obtained by optical microscopy (OM). In Figure 5a it can be observed the high volume fraction of irregular porosity ( $\% \mathrm{P} \cong 8 \%$ ) near the substrate surface ( $3 \mathrm{~mm}$ thick) indicating a deposition process with high volume fraction of solid particles ${ }^{19,20}$. Figure $5 b$ shows the microstructure associated with the $10 \mathrm{~mm}$ thick region of the deposit. It seems that the high liquid fraction deposition in such region can be effective to reduce the porosity ( $\% \mathrm{P} \cong 4 \%$ ), with a predominance of spherical-type porosity. Figure 5 depicts, in the transversal section of the deposit, a more refined microstructure in the bottom part ( $3 \mathrm{~mm}$ thick) with a mean $\lambda_{1}$ value of $6 \mu \mathrm{m}$ and a coarser microstructure in the top part (10 mm thick) with a mean $\lambda_{1}$ value of $12 \mu \mathrm{m}$ and the crystalline phases identified as $\alpha$-Al matrix (grey) and $\mathrm{Al}_{3} \mathrm{Ni}$ intermetallic (dark). Nevertheless, it is difficult to correlate the cell spacing with the cooling rate for the deposit due to the association of the thermal history of the previously atomized powder particles and the subsequent heat treatment (annealing) during deposition.

The DSC curve during heating $(40 \mathrm{~K} / \mathrm{min})$ shows the presence of an exothermic reaction which can be correlated with a crystallization peak of an amorphous phase fraction for the smallest $\mathrm{Al}-5 \mathrm{Ni}$ overspray powder size range, as can be seen in Figure 6. The inset in the DSC graphic shows a SEM image of an amorphous (featureless) powder around $15 \mu \mathrm{m}^{19,20}$. The presence of an amorphous phase is a reasonable hypotheses considering the cooling rates prevailing during solidification of very fine powders, $10^{5}-10^{6} \mathrm{~K} / \mathrm{s}$. This is an indication that a completely amorphous structure may be obtained by meltspinning despite the low nickel content $(2.5$ at.\% Ni) of the

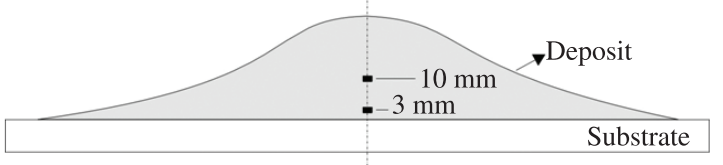

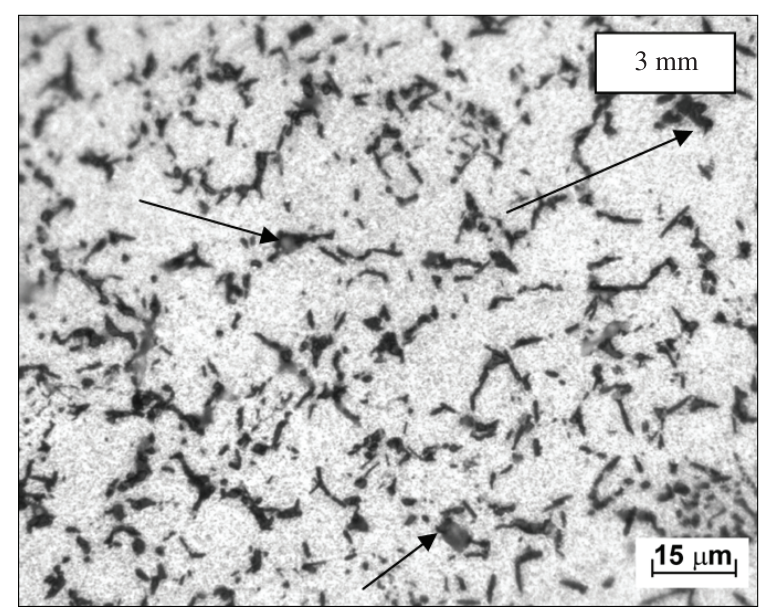

(a)

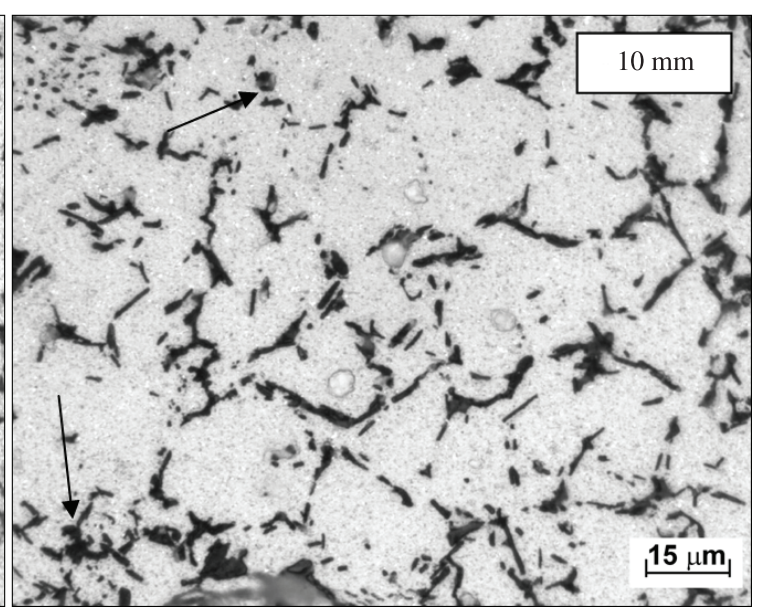

(b)

Figure 5. Transversal microstructures of the Al-5Ni alloy deposit at the positions a) $3 \mathrm{~mm}$ and b) $10 \mathrm{~mm}$ from the carbon steel substrate surface. 


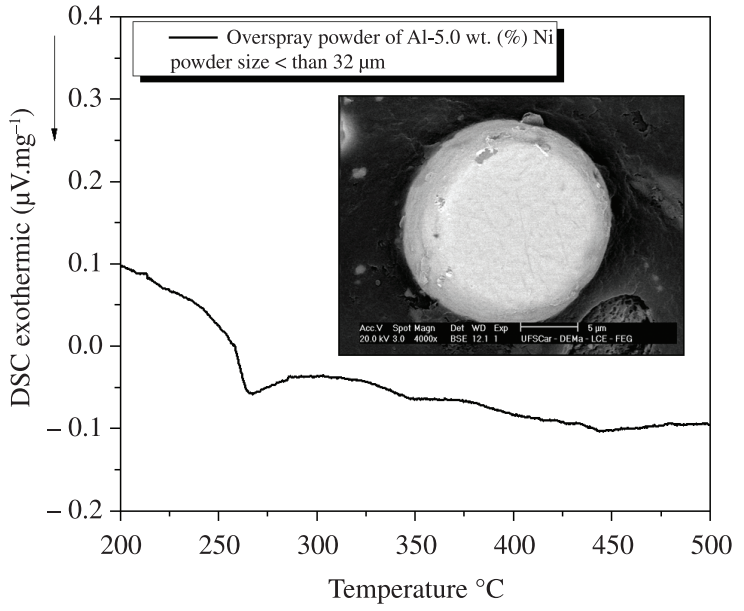

Figure 6. DSC curve for the overspray powder of Al-5Ni alloy in the size range $<32 \mu \mathrm{m}$. The inset in the DSC graphic shows a SEM image of an amorphous (featureless) powder around $15 \mu \mathrm{m}$.

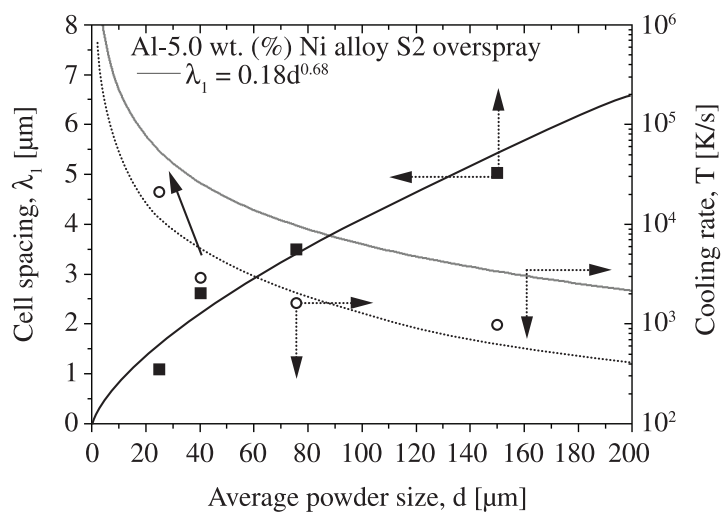

Figure 7. Microstructure length scale and experimental cooling rate against powder size for Al-5.0wt. (\%)Ni alloy. Gray line refers to the calculations with Shiwen's model.

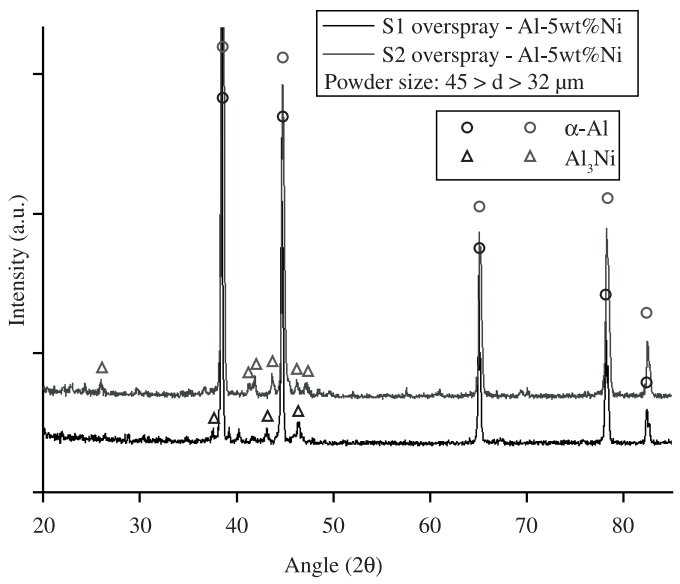

Figure 8. Typical XRD patterns for the $\mathrm{S} 1$ and $\mathrm{S} 2$ overspray powders.

studied alloy. The average size, the size distribution and the volume fraction of the Al-Ni intermetallics, as well as the amorphous structure, deserve a deeper investigation, including an analysis by transmission electron microscopy (TEM).
Due to the wide range of powder size, a significant variation of cell spacing was expected to occur. This can be really observed in Figure 7 with the plot of $\lambda_{1}$ as a function of the average powder size diameter. A power function $\lambda_{1}=0.18 \mathrm{~d}^{0.68}$ fits adequately the experimental measurements. A correlation coefficient $\left(\mathrm{R}^{2}\right)$ of 0.92 has been determined from the power-function regression. The calculations performed with the Shiwen model (gray line) can also be seen in Figure 7. The model overestimates the experimental scatter with some approximation for smaller mean powder diameters $(<40 \mu \mathrm{m})$.

A sudden increase in the cooling rate can be observed for the finest powders (indicated with a solid arrow), which may be conducive to the accomplishment of a critical value avoiding crystalline phases to be formed or preventing that these phases predominate in the whole structure.

Figure 8 shows typical XRD patterns of Al-5.0 wt. (\%) $\mathrm{Ni}$ alloy samples corresponding to $\mathrm{S} 1$ and $\mathrm{S} 2$ powders, with the same crystalline phases identified for both products. A high degree of crystallinity is observed in the intermediary Al-5Ni powder size range ( 45 to $32 \mu \mathrm{m}$ ) despite the rapid cooling rates imposed during the atomization step. The major reflexes were assigned to fcc $\alpha-\mathrm{Al}$ and orthorhombic $\mathrm{Al}_{3} \mathrm{Ni}$ phases.

Due to the variation in the average $\lambda_{1}$ values referring to the powder sizes of the cold compacted Al-5 wt. (\%)Ni alloy samples $(<180 \mu \mathrm{m})$, the microhardness values varied from 68 to $84 \mathrm{HV}$. The microhardness values of the rapidly solidified (RS) alloys have increased up to $58 \%$ when compared with those of the DS samples ${ }^{15}$, despite the presence of porous within the RS cold pressed samples. Lower cell spacings contribute to a more extensive distribution of rod-like $\mathrm{Al}_{3} \mathrm{Ni}$ intermetallic fibers. If these hard particles are better distributed throughout the intercellular regions higher hardness values can be expected. The hard intermetallic phase reinforces the ductile Al-rich phase (supersaturated with $\mathrm{Ni}$ solute due rapid quenching) of the eutectic mixture located in the intercellular regions, which would lead to improvements in the mechanical strength.

The cold pressing process of Al-Ni powders obtained by spray forming with higher gas-to-metal ratio (G/M) presents the possibility of generating low solute content Al-Ni alloys with high hardness no matter if the prevalent structure is formed by an amorphous phase or a cellular array. Commercial materials with low porosity and appreciable strength can be prepared further by an extrusion process.

\section{Conclusions}

A complete characterization of the promising RS Al-5.0wt. (\%)Ni alloy was performed. To the authors knowledge this is the first report concerning the formation of amorphous phase during spray forming of a binary Al-5Ni alloy.

The experimental cooling rates were inferred by measuring the cell spacing of the obtained powders. The experimental result is roughly consistent with the corresponding result calculated by the Shiwen model. An abrupt increase in the cooling rate for the smaller Al-5Ni powder size range $(<32 \mu \mathrm{m})$ seems to be responsible 
for the presence of amorphous phase despite the low solute content of the alloy $(2.5$ at.\% Ni) in particles up to $15 \mu \mathrm{m}$.

The evolution of $\lambda_{1}$ with the powder size (d) was shown to be described by an experimental power law given by: $\lambda_{1}=0.18 \mathrm{~d}^{0.68}$. Future work is now in progress in order to evaluate both the mechanical and corrosion properties by preparing bulk Al-Ni samples by warm consolidation of overspray powders without significant modifications on the RS structure.

The microhardness values in the range of 68 to $84 \mathrm{HV}$ of the rapidly quenched $\mathrm{Al}-5 \mathrm{Ni}$ alloy through spray forming increased up to $58 \%$ when comparing the cold compacted overspray powder $(<180 \mu \mathrm{m})$ with the directionally solidified

\section{References}

1. Tourret D, Reinhart G, Gandin CA, Iles GN, Dahlborg U, Calvo-Dahlborg $\mathrm{M}$ et al. Gas atomization of Al-Ni powders: Solidification modeling and neutron diffraction analysis. Acta Materialia. 2011; 59(17):6658-6669. http://dx.doi. org/10.1016/j.actamat.2011.07.023

2. Catto FL, Yonamine T, Kiminami CS, Afonso CRM, Botta WJ and Bolfarini C. Amorphous phase formation by spray forming of alloys $\left[\left(\mathrm{Fe}_{0.6} \mathrm{Co}_{0.4}\right)_{0.75} \mathrm{~B}_{0.2} \mathrm{Si}_{0.05}\right]_{96} \mathrm{Nb}_{4}$ and $\mathrm{Fe}_{66} \mathrm{~B}_{30} \mathrm{Nb}_{4}$ modified with Ti. Journal of Alloys and Compounds. 2011; 509:S148-S154. http://dx.doi.org/10.1016/j. jallcom.2011.02.026

3. Afonso CRM, Bolfarini C, Botta WJ and Kiminami CS. Spray forming of glass former $\mathrm{Fe}_{63} \mathrm{Nb}_{10} \mathrm{~A}_{14} \mathrm{Si}_{3} \mathrm{~B}_{20}$ alloy. Materials Science and Engineering: A. 2007; 449-451:884-889. http:// dx.doi.org/10.1016/j.msea.2006.02.393

4. Lavernia EJ, Baram J and Gutierrez E. Precipitation and excess solid solubility in magnesium-aluminum-zirconium and magnesium-zinc-zirconium processed by spray atomization and deposition. Materials Science and Engineering: A. $1991 ; 132: 119-133$. http://dx.doi.org/10.1016/09215093(91)90368-W

5. Lee HY, Jung SH, Lee SY and Ko KH. Alloying of Cold-Sprayed Al-Ni Composite Coatings by Post-annealing. Applied Surface Science. 2007; 253:3496-3502. http://dx.doi. org/10.1016/j.apsusc.2006.07.053

6. Shi D, Wen B, Melnik R, Yao S and Li T. First-principles studies of Al-Ni intermetallic compounds. Journal of Solid State Chemistry. 2009; 182:2664-2669. http://dx.doi.org/10.1016/j. jssc.2009.07.026

7. Vojtech D, Prusa F and Michalcová A. Structural and mechanical characterization of rapidly solidified $\mathrm{A} 195 \mathrm{Ni} 5$ and $\mathrm{Al}_{93} \mathrm{Ni}_{5} \mathrm{Mm}_{2}$ alloys prepared by centrifugal atomization. Journal of Alloys and Compounds. 2010; 506:581-588. http:// dx.doi.org/10.1016/j.jallcom.2010.07.081

8. Zhuang YX, Zhang XM, Zhu LH and Hu ZQ. Eutectic spacing and faults of directionally solidified $\mathrm{Al}-\mathrm{Al}_{3} \mathrm{Ni}$ eutectic. Science and Technology of Advanced Materials. 2001; 2:37-39. http:// dx.doi.org/10.1016/S1468-6996(01)00023-7

9. Hunt Junior WH. New directions in aluminum : Based P/M materials for automotive application. Powder Metallurgy. 2000; 36(6):51-60.

10. Cheung N, Cruz KAS, Canté MV, Spinelli JE, Ierardi MCF and Garcia A. Numerical and experimental analysis of rapidly solidified laser remelted Al 5wt pct Ni samples. International Journal of Microstructure Materials Properties. 2010; 5:193-208. http://dx.doi.org/10.1504/IJMMP.2010.035939 samples, despite the presence of porosity in the cold pressed samples. The hard intermetallic phase reinforces the ductile Al-rich phase (supersaturated with $\mathrm{Ni}$ solute due to the rapid quenching) of the eutectic mixture located in the intercellular regions, which would lead to an improvement in the mechanical strength of the alloy.

\section{Acknowledgements}

The authors acknowledge the financial support provided by FAPESP (The Scientific Research Foundation of the State of São Paulo, Brazil) and CNPq (The Brazilian Research Council).

11. Gogebakan M, Uzun O, Karaaslan T and Keskin M. Rapidly solidified Al-6.5 wt.\% Ni alloy. Journal of Materials Processing Technology. 2003; 142:87-92. http://dx.doi.org/10.1016/S09240136(03)00466-7

12. Lapin J, Ondrus L and Nazmy M. Directional solidification of intermetallic Ti-46Al-2W-0.5Si alloy in alumina moulds. Intermetallics. 2002; 10:1019-1031. http://dx.doi.org/10.1016/ S0966-9795(02)00119-X

13. Fan J, Li X, Su Y, Guo J and Fu H. Dependency of microhardness on solidification processing parameters and microstructure characteristics in the directionally solidified Ti-46Al-0.5W-0.5Si alloy. Journal of Alloys and Compounds. 2010; 504:60-64. http://dx.doi.org/10.1016/j. jallcom.2010.05.095

14. Kong CJ, Brown PD, Harris SJ and McCartney DG. Analysis of microstructure formation in gas-atomised Al-12wt. (\%) Sn-1wt. (\%)Cu alloy. Materials Science and Engineering: A. 2007; 454-455:252-259. http://dx.doi.org/10.1016/j. msea.2006.11.050

15. Canté MV, Spinelli JE, Cheung N, Ferreira IL and Garcia A. Microstructural development in Al-Ni alloys directionally solidified under unsteady-state conditions. Metallurgical and Materials Transactions A. 2008; 39:1712-1726. http://dx.doi. org/10.1007/s11661-008-9536-Z

16. Gunduz M and Çardili E. Directional solidification of aluminium-copper alloys. Materials Science and Engineering: A. 2002; 327:167-185. http://dx.doi.org/10.1016/S09215093(01)01649-5

17. Kurz W and Fisher JD. Fundamentals of Solidification. Switzerland: Trans Tech Public; 1992.

18. Shiwen H, Yong L and Sheng G. Cooling Rate Calculation of Non-Equilibrium Aluminum Alloy Powders Prepared by Gas Atomization. Rare Metal Materials and Engineering. 2009; 38:353-356.

19. Afonso CRM, Bolfarini C, Kiminami CS, Bassim ND, Kaufman MJ, Amateau MF et al. Amorphous phase formation during spray forming of $\mathrm{Al}_{84} \mathrm{Y}_{3} \mathrm{Ni}_{8} \mathrm{Co}_{4} \mathrm{Zr}_{1}$ alloy. Journal of Non-Crystalline Solids. 2001; 284:134-138. http://dx.doi. org/10.1016/S0022-3093(01)00392-1

20. Afonso CRM, Bolfarini C, Kiminami CS, Bassim ND, Kaufman MJ, Amateau MF et al. Amorphous phase formation in spray deposited AlYNiCo and AlYNiCoZr alloys. Scripta Materialia. 2001; 44:1625-1628. http://dx.doi.org/10.1016/ S1359-6462(01)00787-4 